\title{
The View of the Ecumenical Synods on the State
}

\author{
By JOHANNES \\ Metropolitan of Helsinki
}

When one wants to learn to know the basic principles of the Ancient, undivided Church concerning the State, as authoritatively and validly as possible, one has to turn to the teachings of the so-called Ecumenical Synods, which is the term used of those great synods of the bishops which were recognised as representing the mind of the Church and whose declarations and rulings thus were-and are, from the Orthodox point of viewbinding on the whole Church. The period, during which the said synods of the ancient Church took place, falls between the $4^{\text {th }}$ and the 8 th centuries, the latest of them being held in 787 . In the present short paper we intend to investigate some of the most characteristic traces in the synodical teachings regarding the State, directly and indirectly.

The material, which constitutes the heritage of the Ecumenical Synods, is very extensive. ${ }^{1}$ As to its character, it can be divided into various entities and consequently classified on various grounds, but for our purpose it seems most practical to study first those rulings and decisions which are called canons, and then, separately, various other elements contained in the minutes.

The canons of the synods offer a very limited basis for our study of the synodical standpoint concerning the State, at least as to the extent of the material in question. There exist less than a dozen canons, which deal directly-at least in part-with matters related to the State. Since the canons of this category are so few, we have to pay quite a special attention to them and to attach a particular significance to the principles expressed through them.

1 Of the canons alone there are more than 800 . The minutes of the various sessions etc. comprise thousands of pages. Cf. J. Mansi, Sacrorum Conciliorum Nova et Amplissima Collectio, Florentiae et Venetiis 1757/58, Parisiis I 899-1927. 
When looking upon the canons of the synods we have to bear in mind, among other things, that the Ecumenical Synods all took place within the Byzantine Empire and usually in close cooperation with their Imperial Majesties. Against this background it is to be noticed quite particularly that the synods, in a surprisingly strong and clear way, as a matter of fact, emphasise the independence of the Church from the State authorities, as regards matters which are important and essential for the life of the Church. In this sense it is both interesting and remarkable to see that the VII Ecumenical Synod, convened by an imperial sacra, very firmly and absolutely condemns any intervention by the State in the elections of bishops, presbyters and deacons. How strictly this is to be followed and how serious are the consequences of breaking this general rule, is seen from the statement that in case a bishop has obtained his jurisdiction over a particular church, e.g., thanks to the secular authorities, he shall be both deposed and excommunicated. But not even this is enough: the synodical fathers go still further by resolving that whoever remains in communion with such a bishop, he, too, shall be excommunicated. ${ }^{1}$ Whether or not this principle was observed always in the practice, too, is outside the scope of the present study, and the thing that matters is the vindication of the principle in question and the formulation and expression thereof. Here the Church makes a clear and in itself significant distinction between the sphere of action of the State and that of the Church herself, in fact from the theological point of view, since it is also stated that an election made by the secular powers stands null. ${ }^{2}$ This implies, in other words, that the Church asserts and proclaims that there exists an area, where the State, however mighty it be, is incapable of exerting certain functions. If the State tries to act, in spite of all, the result is null. From the theological point of view this does not constitute a problem, ${ }^{3}$ but the interesting and remarkable thing is that the practical consequences, which are solely nega-

${ }^{1}$ Cf. VII: 3 and Apostolic Canon 30.-The Roman figures denote the number of the Ecumenical Synod in question, while the Arabic figures refer to the number of the canon concerned.

a VII: 3 .

${ }^{3}$ Only the bishops have the power of ordination. Cf. Apostolic Canon 2 a nel Ancyra 13. 
tive from the State's point of view, are so strongly underlined and so openly expressed even in the atmosphere of the Byzantine Empire.

The canonical material shows, however, that the State may have a positive function, too, from the Church's point of view. Thus we observe that the representatives of the State may be expected to give their assistance to "the common mother, the Catholic Church" in order to strengthen the authority of her leaders, if need be. ${ }^{1}$ Likewise the Church may ask for the measures of the highest authorities of the State in order to make the atmosphere and life of the society as free from non-Christian elements as possible. In the light of these principles it becomes quite obvious that the Church does not expect the State to be neutral, as it were, concerning the matters of religion, but that the State, on the contrary, is to support the task of the Church, from the point of view of external conditions and within the limits laid down by the Church. Again, the principle, as such, is significant, how ever many problems there may have been connected with the application thereof. It is worth noticing, in the present connection, that the Church does not merely call upon the State to act as regards the Christian character of public life, but that she, in certain cases, may try to give rules in a direct way in these matters, which shows that the Church does not want to exert indirect influence as to the external conditions of the society, by means of the authorities of the State, but immediate influence, too. However, the motivation is ecclesiastical and directly related to central Christian values. ${ }^{3}$ It should be noticed, furthermore, that this attitude of the Church quite evidently is based on the conviction that due respect for Christian values is something that very naturally can be expected from the State: the wording of the standpoint of the Church does not express a mere wish but a very general statement which is not qualified in any restrictive way: "there must not be". ${ }^{4}$ Here we clearly-although in a seemingly modest and unimportant way-have the idea of a uniformly Christian State expressed by means of certain rules of practical nature concerning the public atmosphere of the Easter Week. In some other cases we find material

\footnotetext{
1 African Code 67.

2 African Code 84 .

3 VI: 66.

${ }^{4} \mathrm{Ib}$.
} 
which indicates that such a positive attitude or such measures are asked for in order that the external circumstances may support the endeavours of the Church and the spiritual welfare of her individual members, even against their wishes, if need be. The latter principle is of particular interest as it shows that at least in certain cases the authorities of the State are supposed to act, in the interest of the Church and at the request of the responsible ecclesiastical leadership, even against the superficial and basically nonChristian wishes of the people. ${ }^{1}$ This implies, among other things, that the State is expected to serve certain right goals and causes rather than to be a means in the hands of the majority regardless of the quality of the demands of the many, from the Christian point of view. Here, again, it becomes evident that the State is not thought to be neutral or indifferent, not even tolerant, as regards religious attitudes, but expressly on the side of the Church and a supporter of her claims and needs, when the Christian colour and quality of the conditions of life are concerned.

In the light of the above it is easily understood why the person of the Emperor of the Romans has a clearly Christian character according to the synodical material. Particularly in certain liturgical connections this is so manifest that this exceptional rôle of the Emperor seems quite remarkable and almost confusing, from the customary point of view, as the line between clergy and laity is not consistently maintained regarding the person of His Imperial Majesty, who is allowed to enter the Holy Sanctuary, which is forbidden for laymen. Although this right or rather this exceptional privilege is not granted in a general way, but only on a certain condition, viz. in order to enable him to offer his gifts to be used at the Holy Eucharist, it is particularly note-worthy, as it seems to indicate a kind of undefined idea of the emperor as a persona mixta between the clergy and the laity.2 It should not be forgotten, however, that there is, in the synodical material, no attempt at a theological motivation regarding the said principle, but just a reference to an ancient tradition, concerning whose origin or character nothing is said. ${ }^{3}$ On the basis of synodical material it is not possible to judge here the possibility of external, non-Christian influence and the rôle of the

\footnotetext{
${ }^{1}$ African Code 6r.

2 VI: 69 .

${ }^{3} \mathrm{Ib}$.
} 
older Roman tradition.- - In this connection it may be mentioned, furthermore, that when the fathers of the synods discuss the veneration of the icons, they may refer, by way of explanation, to the veneration due to the images of the Emperor, which was met by the people with lights and incense: it is expressly pointed out that the veneration was not given to the picture in its material sense, but to the Emperor himself. The interesting point is that the fathers, when spealsing of the matter in question, do not find any reason to make any negative comment on the said custom. ${ }^{1}$

In our material we find still certain principles, which in their own way, seem to stress the dividing line between the secular and the ecclesiastical functions, thus throwing some light upon the synodical view of society and its nature. This material shows, among other things, that the clergy are expected to take care of their own duties and to avoid tasks which are not in harmony with their calling and ordination. Obviously this way of thinking is meant to have a broad and general validity, as it is to pertain to various types of secular offices and posts. ${ }^{2}$ Against this background it seems obvious that the distinction between the secular and the ecclesiastical is not made simply to assert the independence of the Church from the State, i.e. merely in the interest of the spiritual sphere, but for far more general reasons, viz. owing to the mutually different character of both. It may be worth noticing that this distinction is clearly maintained also as regards property: if it belongs to the Church, it shall remain to serve its own purpose and it must not at any price be handed over into the hands of secular princes. ${ }^{3}$

Here above we have dealt with various canonical attitudes concerning chiefly the rights or the functional limitations of the State and its high representatives. As we have seen, there is, in our material, almost nothing which could be said to express or reflect a myth of the State. Furthermore, the matter-of-fact terms and phrases used hardly indicate any exalted veneration regarding the authorities of the State, however surpriang this may seem to be. In the synodical material there are, however, also elements of another character, not in the canons but mainly in other parts of the minutes related to discussions, speeches etc. This implies, that the elements

\footnotetext{
${ }^{1}$ Cf. Mansi, XII, col. Ior 4 .

${ }^{2}$ VII: 10, IV: 3 and 7, Apostolic Canon 8I, and African Code 16.

s VII: 12.
} 
in question may be said to correspond to the spirit of the synods, but not necessarily to the letter of the decisions, which speak of actual rights and duties or state principles of importance. On the other hand the elements complete in such a way our picture of the ecclesiastical view of the State and its representatives, that it is necessary to pay some attention to them.

The synodal letter of the first Ecumenical Council shows that the Emperor is characterised as "our most religious sovereign" 1 and it is also worth observing that according to the letter the synod assembled "through the grace of Christ and the Emperor". ${ }^{2}$ Thus the latter's person is clearly exalted. In other similar connections we find corresponding phrases regarding the imperial majesty. The fathers of the second Ecum. Council also use the expression "Your Piety"3 and they stress strongly the positive rôle of the State when they maintain that God had made the Empire for the common peace of the Churches and for the support of the true faith. They wish, furthermore, that God may establish the Empire in peace and righteousness and prolong it. Interestingly enough they also ask the Emperor to ratify what has been decreed by them, although there is in the canons nothing to support such a practice. The Emperor is also characterised as most truly pious and beloved by God. ${ }^{4}$ The fourth synod speaks of the religious decree of the Emperors and calls Their Majesties Christ-loving. These expressions, too, occur in an official synodal letter. ${ }^{5}$ (In passing we may notice that this way of thinking corresponds to the line of the Emperors themselves, for in their so-called sacra regarding the seventh Ecumenical Synod they call themselves "the Sovereigns of the Romans in Faith", ${ }^{6}$ which in reality seems to contain even more than the phrases used by the Synods). - As to the positive significance of secular factors to the Church, it is also remarkable that the revered rôle and the great privileges of Constantinople, from the ecclesiastical point of view, have a basis in the secular role of the said city: it is expressly maintained that the city should have its ecclesiastical status of honour, because it is New Rome, i.e. the new capital and because it is honoured

\footnotetext{
${ }^{1}$ Mansi, II, col. 92 I f.

$2 \mathrm{Ib}$.

${ }^{3}$ Mansi III, col. 557 .

4 Ib.

${ }^{5}$ Mansi VII, col. I05 ff.

${ }^{6}$ Mansi XII, col. I30 f.
} 
with the Sovereignty and Senate. ${ }^{1}$ The same principle occurs also in certain other cases, but they can be regarded as applications of the same main idea regarding the administrative significance of political centres and districts. ${ }^{2}$

The material which we have dealt with thus seems to indicate that the Church of the Seven Synods, the undivided ancient Church, far from adoring the State and its representatives, tried to maintain a clear line of distinction between the spheres of Church and State, at least in everything of significance, but showing, on the other hand, by means of phrases and various polite expressions, that the State and Their Imperial Majesties very definitely have a positive function, from the Church's point of view, and a given relation to the life of the Church. This is the picture which we obtain on the basis of the most authoritative decisions and teachings of the Church. It is known to all of us that the history of the Church offers an abundant material also of another kind, but it reflects other points of view than those presupposed by our theme.

IV: 28 .

2 IV: 17 . 